\title{
High School
}

National Cancer Institute

\section{Source}

National Cancer Institute. High School. NCI Thesaurus. Code C89278.

A secondary school that usually includes grades 9 through 12. 